\title{
PERSON'S SEXUAL SCRIPTS IN THE CONTEXT OF HOME SEX EDUCATION
}

\section{Hupalovska V. A.}

\section{INTRODUCTION}

Sexuality as an integral characteristic of person can be traced at different levels of interaction of a person with others (psychological, social, behavioral, cultural). It is possible to observe sexuality directly at the behavioral level, as it is in the behavior of people that there is a certain scenario (script) that applies to all the elements of sexuality.

The concept of the sexual script was introduced by the sociologists J. Gagnon and W. Simon ${ }^{1}$. Subsequently, sexual scenarios were researched by M. Wiederman ${ }^{2}$, J. Kimmel ${ }^{3}$, M. Bernston ${ }^{4}$, S. Dworkin ${ }^{5}$, J. Farrer ${ }^{6}$, S. Hust ${ }^{7}$, I. Kon $^{8}$, A. Tiomkina ${ }^{9}$, J. Sakaluk ${ }^{10}$, V. Hupalovska ${ }^{11}$ et al.

1 Simon W. Sexual Scripts: Origins, Influences and Changes / William Simon and John H. Gagnon // Qualitative Sociology. 2003. Vol. 26, No. 4. P. 491-497.

${ }^{2}$ Wiederman M. The gendered nature of sexual scripts // Family Journal. 2005. No. 13 (4). P. 496-502.

${ }^{3}$ Kimmel M. The sexual self: The construction of sexual scripts. Vanderbilt University press. 2007. 322 .

${ }^{4}$ Berntson M. College as Context: Influences on Interpersonal Sexual Scripts / Marit Ann Berntson, Kristi L. Hoffman, Tracy L. Luff // Sexuality \& Culture. 2014. 18. P. 149-165.

${ }^{5}$ Dworkin S. Actual Versus Desired Initiation Patterns Among a Sample of College Men: Tapping Disjunctures Within Traditional Male Sexual Scripts / Shari L. Dworkin and Lucia O'Sullivan. The Journal of Sex Research. 2005. Vol. 42, Num. 2. P. 150-158.

${ }^{6}$ Farrer J. Re-Embedding Sexual Meanings: A Qualitative Comparison of the Premarital Sexual Scripts of Chinese and Japanese Young Adults/ James Farrer - Gefei Suo Haruka Tsuchiya Zhongxin Sun / Springer Science+Business Media. 2011. P. 263-286.

${ }^{7}$ Hust S. Scripting Sexual Consent: Internalized Traditional Sexual Scripts and Sexual Consent Expectancies Among College Students / Stacey J. T. Hust, Kathleen Boyce Rodgers, and Benjamin Bayly // Family Relations. 2017. 66. P. 197-210.

${ }^{8}$ Кон И. Сексология / И. Кон. - Москва: Академия, 2004. 384 с.

9 Тёмкина А. Сценарии сексуальности и гендерные различия // В поисках сексуальности: Сборник статей. СПб.: Дмитрий Буланин. 2002. С. 247-286.

10 Sakaluk J. Dominant Heterosexual Sexual Scripts in Emerging Adulthood: Conceptualization and Measurement / John K. Sakaluk, Leah M. Todd, Robin Milhausen, Nathan J. Lachowsky // Journal of sex research. 2014. 51 (5). P. 516-531. DOI: $10.1080 / 00224499.2012 .745473$

11 Гупаловська В.А. Сексуальний сценарій у контексті адаптивності особи // Инновационная наука, образование : монография. Одесса. 2018. Глава 3. C. 72-84. DOI: 10.30888/978-617-7414-52-9.0-036 
Given the close interconnection between sexuality and sexual scenarios, their formation and subsequent development are influenced by the same factors: physiological, psychological, social, cultural, historical, demographic, geographical, etc. Sex education at home, as part of the social aspect of sexuality, is among these factors.

The first environment in which personality, as well as sexuality and sexual scenarios, is formed is family. But for the general education there is also a sex one (even when parents deny or ignore the sexual component). Intra-family relationships become for a child a sample to follow and the basis of their behavior outside the family environment.

Of course, throughout childhood the family does not remain the sole source of information for a child, however, any new information will relate to this very foundation laid down by the family.

Insufficient research of the types of sex education and their relation to sexuality and sexual scenarios offers a wide field for research and development of practical recommendations.

\section{Theoretical reflections on sexual scenarios}

Numerous theoretical and empirical studies indicate that the main part of sexual behavior is determined by the scenario identified by the individual themselves ${ }^{12}$. This concept is close to the concepts of 'plan', 'scheme' or 'behavioral program'. It allows to reveal the content of sexual behavior as a socio-psychological phenomenon and to emphasize the importance of the individual's social experience in the process of sexual socialization ${ }^{13}$.

Throughout the entire psycho-sexual and -social process of a person's development, their sexual behavior is formed as such, which is adapted to the socio-cultural norms and satisfies actual needs. When there is a mismatch between the desired (i.e. needs) and the real (i.e. certain norms), a person has to form new models of behavior that will be adequate to such situations now and in the nearest future. This is approximately how sexual scenarios of an individual are formed and undergo changes, which are designed to facilitate the search and selection of a particular behavioral model that would meet all the current requirements.

There are several approaches to determining the essence of the sexual scenario and its significance in human life. For instance, the scenario is defined as the sequence and range of actions, strategies of sexual behavior,

\footnotetext{
${ }^{12}$ Simon W. Sexual Scripts: Origins, Influences and Changes / William Simon and John H. Gagnon // Qualitative Sociology. 2003. Vol. 26, No. 4. P. 491-497.

13 Гупаловська В.А. Сексуальний сценарій у контексті адаптивності особи // Инновационная наука, образование,.: монография. Одесса. 2018. Глава 3. C. 78. DOI: 10.30888/978-617-7414-52-9.0-036.
} 
dynamics of couples' behavior ${ }^{14}$. Such approach focuses on the behavioral aspect of sexuality. It views sexual scenarios as a way of expressing an individual's sexuality in the context of culture. The ideas expressed by I. Kon can be attributed to this approach. In his earlier works, he defined the sexual scenario as a cognitive structure that combines a variety of symbolic and nonverbal elements into an organized and chronologically consistent behavior chain on the basis of which people can simultaneously anticipate and evaluate their own behavior ${ }^{15}$. In his later works, the cultural component is more clearly traced in his definition of the sexual scenario: 'The sexual scenario is a mental pattern that is determined by the culture and is largely unconscious, and through which people organize, comprehend and evaluate their own sexual behavior' ${ }^{16}$.

Also, in the context of the cultural aspect of sexuality, I. Kon notes that the culture itself not only indicates the directions of sexual energy release, but also forms a specific scenario of an individual's sexual behavior, their psychosexual attitudes ${ }^{17}$. That is, the cultural aspect of sexuality, although it applies to society as a whole, can influence individual forms of behavior. In this way, a certain spectrum of sexual behavior, which will be considered normal and not condemned by the society, and yet will remain individual to each separate representative, is being formed.

Another vision of the sexual scenario defines it as a means of representation by the subject of external reality as the object of their desires ${ }^{18}$. Ye. Kaschenko points down that due to the certain ambiguity of the term 'sexual scenario', it is often considered solely within its constituents, without reference to other mental processes of an individual. The sexual scenario should be viewed within the system of general regulatory mechanisms of the personality ${ }^{19}$. As far as the sexual scenario is a unique way of reconciling the surrounding reality with the actual desires and abilities of the individual, it is important to consider other characteristics of mental activity.

The scenario can also be understood as a discursive way of sequential organization of sexual practices. These discursive ways are 'external' in relation to the individual biography. They, like cultural scenarios, create

${ }^{14}$ Каган В.Е. Половое воспитание детей. Москва: Педагогика, 1988. С. 74.

${ }^{15}$ Кон И. Сексология Москва: Академия, 2004. 384 с.

16 Воронцов Д. В. КВИР-теория: перспективы психологического анализа сексуальности. Вопросы психологии. 2012. № 2. С. 153-162.

${ }^{17}$ Кон И. Сексология / И. Кон. Москва: Академия, 2004. С.21.

18 Гупаловська В.А. Сексуальний сценарій у контексті адаптивності особи // Инновационная наука, образование : монография. Одесса. 2018. Глава 3. С. 75. DOI: 10.30888/978-617-7414-52-9.0-036.

${ }^{19}$ Кащенко Е. Психология сексуальности / Е. Кащенко. Москва: Ridero, 2016. С. 33. 
different possibilities for interpreting sexual behavior ${ }^{20}$. Such approach is proposed by A. Tiomkina. According to the researcher, sexual scenarios characterize the sexual culture that has been absorbed by the individual and has become part of their personality and therefore controls the behavior 'from inside', being the part of its disposition ${ }^{21}$. Under this approach, sexual scenarios include what in the culture is considered sexuality (cultural scenarios) and what individuals consider to be the sexual sphere (individual scenarios).

The implementation of the sexual scenario occurs in the interaction of partners with each other. At the same time there is a continuous conscious and subconscious assessment of what is happening, comparison with ideal and ordinary requests, forecasting the further development of events and their correction $^{22}$.

Almost all approaches to defining sexual scenarios link their origin and further development to the cultural aspect of sexuality. Nevertheless, as far as the cultural aspect is the most general and dependent on other factors (economic, geographical, political, etc.), its impact on each specific individual will be determined not so much by the characteristics of the culture itself, but by the personality characteristics of that individual (for example, level of intelligence, motivation, suggestion, traumatization, etc.)

The specific content of the sexual scenario includes the type of partner, acceptable erotic stimuli, requirements for the place, time and situation of the intimacy, justification of the need and possibility of this intimacy, etc. ${ }^{23}$ In other words, the scenario defines what, with whom, how, when, where, and why the individual wants or does not want / should or should not / approves or does not approve / may or may not sexually do.

At the same time, it should be taken into account that what is observed is the unfolding of not one, but two scenarios - with each partner having their own one. The scenarios cannot coincide completely, and this requires constant correction of your own scenario and linking it to the scenario of your partner. The more scenarios a person has, the greater the chance of further favorable

20 Тёмкина А. Сценарии сексуальности и гендерные различия // Е. Здравомыслова, А. Тёмкина. В поисках сексуальности: Сборник статей. СПб.: Дмитрий Буланин. 2002. C. 250.

${ }^{21}$ Асланян Т.С. Психологічні особливості сексуальної поведінки сучасних жінок / Т.С. Асланян, О.В. Шевельдіна. // Науковий вісник Херсонського державного університету. 2018. № 3. С. 14.

${ }^{22}$ Lehmiller J. The Psychology of Human Sexuality / Justin J. Lehmiller, Ph.D. John Wiley \& Sons. 2014. P. 38.

23 Sakaluk J. Dominant Heterosexual Sexual Scripts in Emerging Adulthood: Conceptualization and Measurement / John K. Sakaluk, Leah M. Todd, Robin Milhausen, Nathan J. Lachowsky // Journal of sex research. 2014. 51 (5). P. 516-531. 
course of events. In contrast, fixed, inflexible sexual behavior is more likely to lead to divergent scenarios, their rejection and conflict between partners. Types of sexual scenarios, classically, differ from one author to another. It has to do with the way these scenarios are studied. Anna Tiomkina identifies the following types of sexual scripts:

- Pronatal - a story about sex life constitutes a story about family and reproductive practices;

- Romantic - a story about love and feelings;

- Communicative - a story about friendship;

- Hedonic - a story about physical practices;

- Market - a story about sex as an exchange/bargain;

- Rewards - a story about sex as a story of self-affirmation and selfrealization ${ }^{24}$. These types of sexual scenarios were outlined in the result of the analysis of ways of sexual interactions in life stories. The empirical array of this study was limited to biographies of two generations, which, according to the periodization of I. Kon and A. Rotkirch, refer to the generation of 'silence' and generation of 'behavioral sexual revolution' ${ }^{25}$. The analysis of the biographies of the representatives of generations that socialized during the Soviet times confirms the transition to pluralizing interpretations of sexuality and the spread of sexual freedom practices.

Another classification of sexual scenarios belongs to the Finnish scholars Suvivuo Pia, Tossavainen Kerttu, and Osmo Kontula ${ }^{26}$. The researchers distinguish between: romantic scenario, rational sex scenario, sexual experience-seeking scenario, sexual desire scenario, and sexual intercourse postponing scenario.

Since the sexual scenario of the individual is viewed as a set of their attitudes, experiences, preferences, and sexuality, it is important to focus on how it is formed. The types of sexual scenarios that were outlined by the researchers and described herein above, relate to the interpersonal level that presupposes the interaction with the partner and adjustment to their own interpersonal sexual scenario. This interaction takes place at the cultural level, that is, there are certain limitations, a framework within which the variation of

24 Гупаловська В.А. Сексуальний сценарій у контексті адаптивності особи // Инновационная наука, образование,.: монография. Одесса. 2018. Глава 3. С. 80. DOI: 10.30888/978-617-7414-52-9.0-036.

25 Тёмкина А. Сценарии сексуальности и гендерные различия // Е. Здравомыслова, А. Тёмкина. В поисках сексуальности: Сборник статей. СПб.: Дмитрий Буланин. 2002. C. 253.

${ }^{26}$ Suvivuo P. "Can There Be Such a Delightful Feeling as This?" Variations of Sexual Scripts in Finnish Girls' Narratives / Pia Suvivuo, Kerttu Tossavainen, Osmo Kontula // Journal of Adolescent Research. 2010. 25(5). P. 669-676. 
the scenarios of each individual is acceptable. As for the intrapsychic level, sexual scenarios are least described here, but they can have the greatest influence on external behavior, as far as self-esteem and self-analysis of the experience lead to a further change of interpersonal scenarios.

If to consider the sexual scenarios of the individual at the intrapsychic and interpersonal levels, we will notice that one personality will always have several actual scenarios. I. Kon was the first one to point to it. Firstly, these are sexual fantasies that the subject never tries, cannot, or even does not want to realize. Secondly, these are the plans of actual behavior that the subject more or less consistently implements. Thirdly, these are the interim benchmarks used in the process of sexual interaction ('if he does this, I will do this'). Fourthly, they resemble memory repository that organizes past sexual experiences into a more or less coherent whole. Thus, the individual scenario contains at least three more levels: sexual desire, sexual values system and real sexual experience.

The content of the script is often not the same at different levels. The presence of sexual desire to a particular object or the necessity to realize it in a certain way does not mean that it will be realized with that particular object and in this particular way. For example, if the desired sexual behavior is in sharp conflict with social norms or is unacceptable due to the psychological characteristics of the individual, then the latter may find another object or method. Conversely, a specific sexual behavior does not mean that it is the best behavior for this person. Sexual motivation caused by sexual desire alone is not enough for a person to act on $\mathrm{it}^{27}$.

For this to happen, the motivation must first of all become a plan, in other words, the intention has to be formed. Creation of intentions follows the elaboration of the most important aspects of attractiveness and opportunity to be realized, and is considered from the point of view of the purpose of action $^{28}$. However, no matter how attractive or worthy the purpose may seem, the transition to the formation of intention does not occur automatically. Obviously, for the intention to be created from this purpose, at least the act of internal approval is required.

Accordingly, it would make sense to single out another level of scenario related to the individual's intentions. Plans and intentions as to the sexual behavior are formed on the basis of peculiarities of desire on the one hand, and attitudes towards certain manifestations of sexuality on the other. Desire

\footnotetext{
${ }^{27}$ Gagnon J.H. Sexual conduct: the social sources of human sexuality / John H. Gagnon, William Simon. Chicago: Aldine, 1973. P. 69.

${ }^{28}$ Lehmiller J. The Psychology of Human Sexuality / Justin J. Lehmiller, Ph.D. John Wiley \& Sons. 2014. P. 124.
} 
and intention interact through a system of sexual values mastered by the individual. Sexual plans and intentions, where the influence of the partner's social norms and scenarios is not taken into account, constitute an individual's 'sexual desireness' (not attraction, but attractiveness - the ability to be motivated by the desire). In other words, 'desireness' refers to the intention towards someone or something in a situation where the possibility of an individual's significant adverse effects due to the impact of sex life morality or scenario mismatch is reduced to zero.

In relation to a particular situation, in addition to the subject's internal (personal) attitudes, intentions are influenced first of all, by social norms related to sexual culture (the cultural scenario by W. Simon and J. Gagnon), according to which the elements of the individual scenario may be desirable, acceptable, undesirable or forbidden within the given culture, and secondly, by the features of the partner's scenario. Equally important is the ability of the individual to adequately assess the situation and the possible consequences of specific sexual activity, their ability to self-control ${ }^{29}$.

When the level of trust in the partner changes, the weight of the influence of the cultural scenario is changed as well. The higher the trust, the more the personal scenario is used, the less common elements it has. Accordingly, the lower the trust, the greater the impact will be on the generally accepted norms and rules, even if they do not coincide with the personal sexual scenario.

\section{Laying the foundations of the sexual scenario at different stages of psychosexual development}

In the context of the cultural scenario, sex education at home aims to communicate to the child the general rules of manifestation of their own sexuality.

In the first stage of psychosexual development, the sexual consciousness is being formed. This period covers ages from birth to 5-7 years. The microsocial environment in which a child grows up has a significant impact here. From birth, parents and closest relatives emphasize the gender of the child and reinforce appropriate behavior that is approving of this gender and in this socio-cultural environment. The very process of emotional response to a child's behavior in accordance with their biological sex will be the sexual education that is carried out in early childhood, when sexual consciousness is just beginning to form, and the outer world is being perceived emotionally, not rationally.

${ }^{29}$ Simon W. Sexual Scripts: Origins, Influences and Changes / William Simon and John H. Gagnon // Qualitative Sociology. 2003. Vol. 26, No. 4. P. 493. 
With the development of cognitive psychic processes and growing curiosity, children begin to ask questions about childbearing, gender differences, etc. The first questions about the breast of the mother, different ways of urination, other anatomic gender differences appear when the child is 2,5-3 years. At about age of 5, questions about the origin of children and birth arise, while up to 7 years children want to know how they find themselves in the womb. Girls start asking questions earlier than boys. The age when the child starts asking these first questions depends on the temperament, curiosity, communicativeness, trust in parents, their attitude to sexual issues. If children do not ask such questions, it means that they consider the topic of sex to be forbidden to discuss with the elders, and satisfy their interest in another way ${ }^{30}$.

The answers to these questions, the atmosphere in which the conversation takes place, the mood of the parents and their emotions create the general tone of sex education that conveys the parents' attitude to sexuality. In any case, the child will adopt the parental attitude. They may develop feelings of guilt and shame for their interest, a desire to conceal from their parents objects of interest (in case of parents' aggressive reaction, direct or indirect threats, etc.) or, conversely, a sense of self-interest, a healthy and normal attitude to the sexual sphere (in case of parents' appropriate reaction).

In the first stage of psychosexual development, the relationship between parents, their attitude towards each other, towards sexuality and its expression, their recognition of the personal space of the child, and the like, will be important and illustrative for the effective sex education. Children are entitled to respect for their intimacy; this brings them respect for the intimacy of others. It is not necessary to emphasize the shame and indecency of the naked $\operatorname{body}^{31}$.

The second stage is the formation of the stereotype of sex-role behavior. This stage is characterized by the intense socialization of the child, the formation of their collective consciousness. At this period the child learns to communicate with peers, his/her emotional reactions improve and differentiate, the prevailing mood is being shaped, the character is formed. The first foundations of the sexual scenario at all its levels are laid.

At this stage, sex education is provided not only by parents, but also by teachers at school. The main task of sex education at this stage will be to prepare schoolchildren for adolescence, to inform them about the psychological and physiological features that await them, to develop a culture of inter-gender relations.

\footnotetext{
${ }^{30}$ Кащенко Е. Психология сексуальности. Москва: Ridero, 2016. С. 14.

${ }^{31}$ Ibid., c. 15.
} 
Lack of proper attention from parents, educators and doctors to sex education, the thought of the asexuality of middle school age children lead to the situation when the necessary sexual education children receive secretly, from unreliable sources. Gender issues are discussed with inadequate terms of a vulgar nature, which leads to further perception of sexuality as something wrong, whatever one should be ashamed of. Such conclusions drawn by the children contrast with the regular development of gender identification and shaping of sex-role behavior, which can cause conflict-neurotic tension, and sometimes - neurotic maladaptation of children ${ }^{32}$.

If in the preschool age the child's psyche was not overwhelmed by feelings of shame and fear of sexuality, and in the early school age sex education was an adequate part of general education, and if by the beginning of puberty children went through an adequate way of choosing and developing sex-role behavior, then during the teenage years there will be almost no difficulties in the development of children and their relationships with parents.

The last stage is the formation of psychosexual orientations. At this stage, the importance of the spontaneous factors of the environment that can create a favorable background for all kinds of sexuality disorders increases. This will be accompanied by inappropriate sexual education or its complete absence. Stages of libido formation at this stage increase the importance of trusting relationships with parents and authorities, which can help teenagers to solve complicated issues as to the attachment, affection, love for a new object. The issues of the onset of sexual life, adolescent unwanted pregnancy, and abortion are exacerbated. Sex education of adolescents at this stage should not only presuppose the adequate information about contraceptive methods and the conception issues, but also be aimed at raising responsibility for their own actions and weighing all the risks for starting or delaying their own sexual life.

At this stage, the acquired elements of the sexual scenario are tested in practice, what helps to gain experience. Sexual scenarios here are actively changing, varying within certain limits set by society, so the individual seeks their own comfortable scenario and an approach to the manifestation of their own sexuality.

\section{Sex education as the basis of a child's sex-role behavior}

Sex education begins in the early childhood in the family setting, where parents lay the foundations of a child's sex-role behavior with the help of words and/or their own example.

Sex education is a set of educational activities aimed at the formation, shaping and development of certain norms and values that apply to all the

\footnotetext{
${ }^{32}$ Кащенко Е. Психология сексуальности. Москва: Ridero, 2016. С. 21.
} 
components of human sexuality. It includes a wide range of areas for educational work that partially represent the components of sexuality:

- biological (biological gender differences, mechanisms of conception and birth of children, puberty, contraception, etc.);

- psychological (personal sexual attitudes);

- behavioral (sexual behavior);

- social (social norms)

- cultural (cultural specificities of sexuality).

Educational component is an integral part of the sex education complex, because if the information is complete and reliable, the risk of acquiring dubious knowledge, forming false beliefs and attitudes, and developing inappropriate sexual behavior is reduced.

V. Kahan also points to the complex nature of sex education. $\mathrm{He}$ emphasizes the overall ultimate goal, noting that the components of sex education include everything that nurtures a healthy and holistic personality of a woman and a man, who are able to adequately understand and comprehend their physiological and psychological characteristics in accordance with existing sociocultural norms and, therefore, with the help of this establish optimal relations with people of opposite sex in all spheres of life ${ }^{33}$.

Sex education is part of both general education at home and school education. Therefore, it is possible to distinguish two types of sexual education: family and school, which includes not only the school as a significant social institution, but also any other group (extracurricular circles and organizations, colleges, etc.) that offers a certain type of behavior.

Family sex education lays the foundations for sex-role behavior, gender identity, self-confidence, trust, etc. At preschool age, the child mostly feels, not comprehends, the surrounding world, thus it is the relationships between parents (the same foundations of sex-role behavior), their attitude to him/her (self-confidence, gender identity) and the child's attempts to gain attention (trust), that will be informative for him/her. Therefore, sex education at home presupposes not only giving a child the necessary information and controlling their behavior (encouraging the desirable behavior and punishing the undesirable one), but also the attitude towards the child, the emotions of the parents, their relationships, etc.

It is due to this emotional component of family sex education that it is an integral part of general education. Even if parents deliberately protect the child from any information related to sexuality, their behavior will determine the basis of further sexual preferences, sex-role behavior, child's confidence, etc.

${ }^{33}$ Каган В.Е. Половое воспитание детей / В.Е. Каган, Д.Н. Исаев. Москва: Педагогика, 1988. C. 18. 


\section{Models of sex education}

The foundations laid by the sex education at home are being developed and expanded within the framework of school sex education. At the same time, family education continues to exist and function within the framework of general education and, as a rule, does not change its direction over time.

According to the classification of the Polish educator and sociologist M. Kozakiewicz (Table 1), there are three main models of sex education:

1) repressive;

2) democratic;

3) liberal.

These types are differentiated on the basis of the information provided and its nature, the characteristics of parents' behavior in the process of providing this information, and the personal attitudes regarding the sexuality of parents. For example, a repressive model provides a minimum of information that a child receives from a parent, a democratic one provides a sufficient amount of information according to the child's request and his/her age, while in the liberal model the child is given complete information, regardless of their age and request, often without evaluative characteristics ${ }^{34}$.

Table 1

Models of sex education according to M. Kozakiewicz

\begin{tabular}{|l|l|l|l|}
\hline $\begin{array}{c}\text { Model of } \\
\text { sex } \\
\text { education }\end{array}$ & $\begin{array}{c}\text { Amount of } \\
\text { information }\end{array}$ & Content of information & $\begin{array}{c}\text { General } \\
\text { tone }\end{array}$ \\
\hline Repressive & Minimal & $\begin{array}{l}\text { Categorical prohibition, } \\
\text { recognition of 'abstinence' } \\
\text { as the only right choice }\end{array}$ & 'No!' \\
\hline Democratic & Sufficient & $\begin{array}{l}\text { Absence of categorical } \\
\text { prohibition, provision of } \\
\text { information regarding } \\
\text { safety and danger of sex } \\
\text { life, encouragement of the } \\
\text { choice of safety. }\end{array}$ & 'Yes, \\
but...' & \\
\hline Liberal & Complete & $\begin{array}{l}\text { Absence of any } \\
\text { prohibitions, giving full } \\
\text { autonomy, lack of safety } \\
\text { control }\end{array}$ & \\
\hline
\end{tabular}

\footnotetext{
${ }^{34}$ Козакевич М. Сексуальное воспитание и молодёжь Европы. София. 1985. 144 с.
} 
In their monograph 'Sex education of children' Dmytro Isaiev and Viktor Kahan describe in details the basic provisions of each type of family sex education.

Repressive type of sex education is most common in religious families. In other cases, repressive education is caused by the inability and unwillingness to provide information about sexuality to children. In general, this type of education is based on the belief that knowledge provokes the desire to put it into practice, and this leads to youth being corrupted. Therefore, the minimum amount of information provided to children under this model of education relates only to the most essential (for instance, the information about menstruation) and, most often, to the religious (abstinence and virginity until the wedding, sinful nature of the sexual desire, the need for full trust and obedience to the elders, family values and roles, etc.).

This model of sex education completely excludes information about anatomical and physiological inter-sex differences. The information about the reproductive function is given later, when the child grows older. Human reproductive processes can be explained by the example of plants. Here the young people should first of all develop a deep understanding of the nature and importance of family and marriage, and only then will it be acceptable to discuss with adults - even educators - the process of puberty, its complexity, sexually transmitted diseases, the variability of sexual behavior form, etc. not accepted $^{35}$.

Proponents of the repressive model of sex education idealize the processes of developing children's curiosity, and do not fully understand the cause-andeffect link between sex education and sexual behavior, they eliminate the possibility of other sources of information than parents, and dismiss the compensatory processes. The constant imposition of ideals and values, the lack of reliable and accurate information, the refusal to explain the reasons for the permanent prohibitions, and more, all compensate for the lack of information from parents. The child is looking for other sources that can tell what is being hidden from him/her. These sources may include peers or older friends, parents of friends, other important adults, the Internet, the media, etc.

In today's world, it is impossible to fully control all the information that comes to a child, and therefore the repressive model of sex education is unreliable. Adherence to its basic principles will not help parents to raise a healthy, aware person, responsible for their actions. Rather, the repressive education fosters a constant and growing sense of guilt for sexual acts, thoughts, desires, etc., because their denial cannot guarantee their absence,

${ }^{35}$ Каган В.Е. Половое воспитание детей / В.Е. Каган, Д.Н. Исаев. Москва: Педагогика, 1988. C. 8. 
because they are an important component of the psychosexual development of any person.

The liberal model of sex education is the antagonist of the repressive one. They are completely opposite, ranging from basic principles and definitions to personal settings of parents and methods of educational processes. If the repressive model identifies sexuality as an irrelevant and unnecessary component for healthy overall development of a person and sees it only as a side effect of procreation, then the liberal type proclaims sexuality as the most important and necessary component for the development of a harmonious personality, often without reference to the reproductive function.

By the volume and nature of information, the liberal model provides the most complete information about sexuality. The main goal is to deprive young people of a sense of guilt for their sexuality that has been promoted by the previous generations. This model of sex education can be regarded as an aggressive response to the prohibitions promoted by the repressive model.

Young people have the right to separately and independently form the desired moral and sexual norms, and no one has the right to impose on them their morals. The only mandatory norm is the responsibility for the nature and consequences of their sexual relations, the use of contraceptives and the birth of children as a result of unintended pregnancy. The production and distribution of pornographic products is based on the right of adults to freely choose what they want to see, have, $\mathrm{do}^{36}$.

The complete opposite of these two approaches to sex education obviously defines their common characteristic - they unequivocally exclude and deny the existence of any other approach.

The democratic model of sex education combines the best features of repressive and liberal models. It provides sufficient freedom for the variability of sexual behavior, while encouraging compliance with one's own safety rules and, most importantly, explains the dangers and ways to avoid them. The democratic approach maintains a positive attitude towards sexuality, but does not counterbalance other important social constructs.

Raising a child by means of the democratic type of the model helps to avoid frustration and harm for others in sexual relationships, facilitate personal and psychosexual development, soften the transition to adulthood, so that the realization of emotional and sexual needs does not violate other people's social norms and well-being ${ }^{37}$. This is ensured by informing children

\footnotetext{
${ }^{36}$ Каган В.Е. Половое воспитание детей / В.Е. Каган, Д.Н. Исаев. Москва: Педагогика, 1988. C. 8.

${ }^{37}$ Ibid., c. 9 .
} 
and young people about current, previous and future processes and changes in their bodies, their relationships with others and their lives in general.

In this way, all components of sexuality are balanced, and the provision of complete and truthful information prevents the acquisition of false knowledge and the formation of incorrect and inadequate attitudes. Granting freedom wen giving complete information ensures the formation of a mature and responsible personality. Admissible sexual activity is determined by age and reciprocity of physical, mental and socio-moral maturity. Early sexual relations are unacceptable because they may violate the interests and wellbeing of partners and a child who may be born in the result of the immature sexual relations. Masturbation and petting are not morally condemned. Partners' loyalty to one another ceases to be equated with sexual exclusivity, which is considered mandatory for marriage, but does not preclude a broader and more liberal understanding; in this respect the requirements for men and women should not differ. The basic moral principle of sexual conduct in or out of wedlock is the following: any type of sexual intercourse is morally permissible if they correspond to the desires and attitudes of mature and morally responsible people who act without external or internal pressure ${ }^{38}$.

Another similar classification of types of sex education at home was proposed by Miriam and Otto Ehrenberg in 1988. The researchers described four types of parents' attitude towards gender issues that manifest themselves in family life and determine the style of sex education: 1) repressive type; 2) avoidant type; 3) obsessive type; 4) expressive type.

As well as in the previous classification, the repressive type here reflects a negative attitude towards sexuality. Sex is considered dangerous and knowledge of it is unnecessary for children. Abstinence until the wedding day is promulgated. In such families, it is forbidden to use specific words and joke about things like that, walk around the house in lingerie, etc.

The avoidant type is characterized by a more tolerant attitude towards sexuality. It is considered as a useful characteristic, but often parents are unable to talk about its features with children ${ }^{39}$.

The obsessive type maintains a positive attitude towards sexuality, but everything related to sex becomes the focus of attention in the family. Such parents are too liberal, often not trying to hide their sexual relations, which can scare their children. This type is similar to the liberal type of sex education.

${ }^{38}$ Каган В.Е. Половое воспитание детей / В.Е. Каган, Д.Н. Исаев. Москва: Педагогика, 1988. C. 8.

${ }^{39}$ Мастерс У. Основы сексологии / У. Мастерс, В. Джонсон, Р. Колодни. Москва: Мир, 1998. C. 258. 
The expressive type also maintains a positive attitude towards sexuality. The issues of interest to children are being openly discussed. Parents explain to children that sexuality is an important and healthy phenomenon in everyone's life, but it is not necessary to focus entirely on $i t^{40}$. The characteristic of the expressive type coincides with the democratic type of sex education according to the classification of M. Kozakiewicz.

The proposed models of sex education can be applied both in family and in school education. In 1994, the American Public Health Association passed a resolution reaffirming the right of children and adolescents to comprehensive sex education. According to the association's recommendations, the manner of presenting facts and information regarding sexuality should not offend pupils' racial, national or personal feelings. Moreover, the association supported the idea of teaching practical skills which will help young people improve their relationships with others and make more responsible decisions about $\operatorname{sex}^{41}$.

It is the striking example of the democratic type of school sex education that was viewed as liberal and later considered to be ineffective and unnecessary. The United States' experience in introducing sex education into the school curriculum contains several 'waves' that are associated with dramatic changes in health of adolescents (unwanted pregnancies, abortions, increasing numbers of sexually transmitted diseases, and others similar problems). This illustrates the general tendency towards intense activity so as to overcome a critical state, instead of actions aimed at preventing this state.

The first wave arose from an effort to reduce the number of unwanted pregnancies and reduce the transmission of sexually transmitted diseases among young people. Sex education presupposed providing adolescents with the information about sexuality, pregnancy, and contraceptives. Similar sex education can be observed in modern Ukrainian schools.

The second wave began with the final conviction that one's knowledge of contraception was not enough to avoid unwanted risky sexual behavior by adolescents. The new program focused on the need to identify and define the sexual values of young people. This program was called the "comprehensive sex education ${ }^{42}$. The expected success was not achieved.

The third wave arose in the 80 's of the $20^{\text {th }}$ century. It was characterized by advocacy of abstinence as the only right strategy for avoiding dangerous sexual behavior. Since the introduction of the new program, no information

${ }^{40}$ Мастерс У. Основы сексологии / У. Мастерс, В. Джонсон, Р. Колодни. Москва: Мир, 1998. C. 258.

${ }^{41}$ Келли Ф. Г. Основы современной сексологии. СПб: Питер, 2000. С. 313.

${ }^{42}$ Ibid. 
has been obtained to confirm that students started abstaining from sexual intercourse before marriage.

The fourth wave of sex education is related to the HIV and AIDS crisis. While ignoring the results of previous programs, the new strategies for sex education tried to inform young people about the risk of unprotected sexual contacts and casual sex.

After the failures and partial successes of all four waves of sex education, certain conclusions have been drawn that point to key mistakes in the implementation of sex education in educational institutions.

Firstly, it was the misconception of the transfer of experience from the older generation to the younger. This approach did not justify itself, because the experience of the older generation in its unaltered and unadapted form will be of little use for today's youth.

Secondly, we need to broaden our perception of sexuality, to include more variability in programs, as far as students' basic perception may differ due to different cultural and national values.

Thirdly, many parents oppose sex education in schools because they consider such education to be a family responsibility, although in reality they pay too little attention to it.

From the theoretical point of view comprehensive sex education is the most effective one, because it can be the most variant and universal. For example, even if a teacher advocates abstinence or advises adolescents to postpone the onset of sexual activity, he/she does not deny young people the opportunity to find out about the reliable contraceptive methods, in the event that they decide to have sexual relations ${ }^{43}$.

A. Shybaieva notes that sex education is carried out as an integral part of the general complex of educational activities in the family, preschools, schools, etc. on the basis of a unified approach on the part of parents, educators, medical workers; is differentiated according to sex, age and degree of preparation of the child (parents) and phased character; provides a favorable atmosphere and hygienic conditions.

Sex education should be based on the common opinion of all educators, carried out in accordance with the age and current knowledge of the child, not humiliate children and not bring up feelings of guilt, shame or fear in them. It is important for the representatives of all genders to know the features of sexuality and sexual development of their own as well as the opposite sex. This will provide a solid basis for further building and developing partnerships. Compliance with these conditions can guarantee the success of sex education.

\footnotetext{
${ }^{43}$ Келли Ф. Г. Основы современной сексологии. СПб: Питер, 2000. С. 317.
} 


\section{Main areas of sex education}

A clear delineation of sex education's areas simplifies and specifies pedagogical work, as it determines what areas of sexuality can be fostered and in what way it is more appropriate to do so. It's necessity to outline the following areas of sex education:

1. Sex-role education. It helps to develop psychological masculinity and femininity and to establish optimal communicative attitudes of men and women.

2. Sex education. It is aimed at optimizing the formation of sexual and erotic orientations and sexual consciousness in the context of psychosexual culture and moral requirements.

3. Preparation for the responsible cohabitation. Forming partnership roles and developing responsible partnership settings.

4. Preparation for responsible parenthood. It involves the formation of role behavior of a mother and a father towards children and development of optimal reproductive attitudes.

5. Development of a healthy lifestyle. It is realized through the clarification of how such bad habits as smoking, alcoholism, drug addiction, sexually transmitted diseases, unwanted pregnancy, etc. affect sexuality, partnership and parenthood ${ }^{44}$.

Therefore, the pedagogical aspect of sex education relates to its educational character. Thus, for comprehensive awareness and development of a harmonious personality, sex education should be carried out according to certain principles in different areas. The success of sex education depends on the authority of the educator, their awareness, openness to children and willingness to help them in solving complex issues, on the clarity of the stated purpose and basic tasks, on the ways and means of teaching.

\section{Psychological-sexual component of sex education}

As it has already been mentioned herein above, sex education can be carried out both within the framework of general family education and within the school educational process. It can be done consciously by parents or teachers, according to a compiled program that takes into account all agerelated physiological and psychological characteristics of children, or unconsciously, when a child is in a particular environment of unstructured information, and determines the significance, accuracy and usefulness of that information on their own. This environment can be the Internet, a group of friends, the media and even art. Provided that at least one of these points is present in the life of the child, conscious selection of information by parents

\footnotetext{
${ }^{44}$ Кон И. Сексология / И. Кон. Москва: Академия, 2004. С. 246.
} 
or teachers is impossible. The only way to protect a child from false, inaccurate, distorted, incomplete information is to provide the necessary knowledge and skills in a timely manner that will relate not only to the sexual topic but also to the features of finding valid information.

Ignorance of specific facts is usually offset by knowledge of basic patterns. Therefore, the sex education system, like any other education, regardless of the method of its implementation (family, school, extracurricular courses, etc.), should be multifaceted and include knowledge not only of sexology, but also of psychology, biology, physiology and useful facts from other, supporting sciences.

The process of sex education always involves the emotional component, regardless of the strategy followed by parents and teachers. In early childhood, this is due to the peculiarities of emotional perception of the world. Emotions for children are more informative than the facts they convey. Therefore, along with information about childbearing and gender differences, the child gets an idea of his/her parents' attitudes towards sexuality. Unconsciously, the child takes over these attitudes, and any further information will be perceived by him/her through the lens of these attitudes. It is important to teach children from an early age to perceive the phenomenon of pregnancy or childbirth calmly. Correct perception of these phenomena is only possible in families where there is mutual trust between parents and children ${ }^{45}$.

Forms and ways of information presentation are also important, as they can keep the child's interest in sexual topics, or vice versa, develop feelings of shame and guilt for that interest. Introducing children to facts alone cannot be considered a full-fledged sexual education. It is advisable to use facts only when introducing children to moral norms. Explanation of moral principles should be supported by some experience. The assessment of educators and parents of the behavior that is acceptable and unacceptable in society creates the basis for the consolidation of the individual system of values, orientations and attitudes. This can only be achieved by creating a supportive environment, not by suggestion or persuasion by force. The goal of sex education is to use the acquired skills and knowledge of children in everyday life, in real-world relationships with other children ${ }^{46}$.

It is advisable to choose different amount and types of information depending on the age of a child, as some facts may shock or psychologically injure them. However, regardless of the age of the child, it is necessary to

\footnotetext{
${ }^{45}$ Каган В.Е. Половое воспитание детей / В.Е. Каган, Д.Н. Исаев. Москва: Педагогика, 1988. C. 5.

${ }^{46}$ Ibid., c. 45 .
} 
use the proper terminology for the names of genital organs, sexual intercourse, etc. It is often that parents use 'infantile' terminology when for the first time explaining the child this topic. At the age of 5-6, the child learns from other peers and older friends about other names for genitals and the process of their use, mainly the cynical ones. These names carry an emotionally negative colouring that can be transferred from certain words to the entire sexuality sphere.

At an older age, when infantile terminology is dismissed as ridiculous and a vulgar one as unacceptable, the 'verbal emptiness' appears in the emotional inter-gender relations. Thus, young people often ignore medical appointments with gynecologists, proctologists and urologists, because it is difficult for them to explain what is their concern. The problems in sexual relations arise as far as the communication between partners is being impaired and couple's confidence suffers as well.

In the process of sex education, it is important for parents and teachers to develop child's confidence in themselves. This can be accomplished in various ways, but it depends largely on the atmosphere in which the conversation takes place, as well as on the behavior of the educator.

But for the parents and teachers, a specialized doctor may also participate in sex education. The peculiarities of this approach are not fully defined, as there are ambiguous opinions regarding doctor's involvement in sex education. Unilateral medical approach to sex education, when the doctor occupies a leading position in the educational process, is considered wrong. As the specialist knowledge holder, the doctor may conduct additional classes but not replace the teacher. The task of the doctor in the process of sex education is to disseminate scientifically substantiated facts regarding healthy sex life and prevention of disruptions to it. Also, doctors' task is to advise parents and teachers as to the health and hygiene issues in sex education. The medical aspect of sex education provides for the formation of a link between sexuality and health issues including sexual health.

Psychological-sexual aspect of sex education concerns the form of information delivery and its age-related differentiation. Forms and methods of its presentation should be appropriate not only to the child's age, but also to their current psycho-physiological condition. The curiosity of the child should be fully satisfied, while developing the concept of norm in interpersonal relationships. Moreover, the information should be provided in such a way that it does not have a traumatic impact on the child, since for many children such information can bring about the whole range of emotions that necessarily need to be discussed. 


\section{CONCLUSIONS}

In the process of theoretical research, the problem of types of sex education at home was analyzed in the framework of various sexual, psychological and pedagogical approaches, as well as the role of sex education in the formation of sexual scenarios. The classification of the types of parents' attitude towards sexuality by Miriam and Otto Ehrenberg was taken as the basis for the study. According to the approach proposed by these researchers, family sex education is determined by the type of parents' attitude towards sexuality. It can be of four types: repressive, avoidant, expressive, and obsessive. In addition to this classification, there is an approach by M. Kozakiewicz who describes three types of sex education: repressive, democratic, and liberal.

The most thorough research in the field of sexology and psychology of sexuality was carried out in the $20^{\text {th }}$ century, when sexology was separated into the independent science (W. Masters, V. Johnson, G. Kelly, J. Money, W. Reich, H. Vasylchenko, K. Imielinskii, et al.). As a consequence, the compulsory sex education programs were developed and implemented in schools, but expectations from these programs were not met due to the low percentage of children who received proper sex education in schools and colleges (a high percentage of parents' refusal of the participation in such programs) and the low level of teachers' preparedness.

Sexual scenarios become a barrier to the free expression of sexuality only if their content is internally condemned by the individual himself/herself. In this case the sexuality becomes a cause of shame and guilt, and sexual interaction either does not bring pleasure at all, or pleasure from it is regarded as something negative and wrong. This may be the case if the strategy of sex education envisaged the formation of attitudes about sexuality and sexual manifestations as unnecessary, sinful, wrong and inappropriate.

If there is no such factor, then the sexual scenarios become ancillary to the manifestation of sexuality, their components are expanded, the experience gained is appreciated and the dynamics of sexuality is observed.

The denial or suppression of sexuality at any stage of its development is inappropriate and provokes the development of further problems: from ignorance of the processes of one's own body to actual psychosomatic disorders. This is why it is extremely important in a timely, dosed and ageappropriate way to provide children with truthful information about what is happening to their body, how it may change, and what are the rules of sexual behavior that should be followed.

At the same time, sex education makes it possible to develop good communication skills, because the confidence between the child and the parents, which is present during adequate sex education, establishes the basis 
for the formation of trusting relationship with others in the future, and as a consequence - of high level of sexual well-being and of sexual scenarios that will be adequate to one's own needs.

In addition to sex education at home, there are many other sources from which children can learn about sexuality and sexual relationships: social contacts with peers, friends, the Internet, school knowledge, teachers, and the impact of attitude shown towards sexuality by the adults that are important for the child. Unfortunately, the reliability of the information received from friends, acquaintances, sometimes from the Internet is almost minimal. They create misconceptions and unhealthy attitude towards child's own sexuality (for instance, fear or disgust), which also hinder normal psychosexual development. In addition to providing the information about sexuality and its manifestations, sex education at home is designed to create a basic sense of trust, safety and well-being that become the basis for further relationships. If there are no trusting relationship in the family that exist between parents, parents and children, adequate sex education will never take place. In adulthood, a person who was brought up in such a family will not be able to be a fully-fledged, psychologically mature partner in their own relationship. The prospects for further research constitute the development of methods of psychological correction of maladaptive sexual scenarios for individuals with different types of family sex education.

\section{SUMMARY}

In the course of the theoretical research, the problem of types of sex education at home was analyzed in the framework of various sexological, psychological and pedagogical approaches, as well as the role of sex education in the formation of sexual scenarios. The classification of the types of parents' attitude towards sexuality by Miriam and Otto Ehrenberg was taken as the basis for the study. According to the approach proposed by these researchers, family sex education is determined by the type of parents' attitude towards sexuality. It can be of four types: repressive, avoidant, expressive, and obsessive. In addition to this classification, there is an approach by $\mathrm{M}$. Kozakiewicz who describes three types of sex education: repressive, democratic, and liberal. Besides providing the information about sexuality and its manifestations, sex education at home is designed to create a basic sense of trust in oneself and others, safety that become the basis for further relationships, sexual and general well-being of the individual. Actually, the information and the way it is presented determine the type of sexual education. Type of sexual education forms the internal structure of sexuality, which is reflected in current sexual scenarios of personality. 


\section{REFERENCES}

1. Simon W., Gagnon J. H. Sexual Scripts: Origins, Influences and Changes. Qualitative Sociology. 2003. Vol. 26, No. 4. P. 491-497.

2. Wiederman M. The gendered nature of sexual scripts. Family Journal. 2005. № 13 (4). P. 496-502.

3. Kimmel M. The sexual self: The construction of sexual scripts: Vanderbilt University press. 2007. 322 p.

4. Berntson M., Hoffman K.L., Luff T. L. College as Context: Influences on Interpersonal Sexual Scripts. Sexuality \& Culture. 2014. Vol. 18. P. 149-165.

5. Dworkin S., O'Sullivan L. Actual Versus Desired Initiation Patterns Among a Sample of College Men: Tapping Disjunctures Within Traditional Male Sexual Scripts. The Journal of Sex Research. 2005. Vol. 42, No 2. P. $150-158$.

6. Farrer J., Haruka G., Zhongxin Sun T. Re-Embedding Sexual Meanings: A Qualitative Comparison of the Premarital Sexual Scripts of Chinese and Japanese Young Adults. Springer Science+Business Media. 2011. P. 263-286.

7. Hust S., Rodgers K., Bayly B. Scripting Sexual Consent: Internalized Traditional Sexual Scripts and Sexual Consent Expectancies Among College Students. Family Relations. 2017. Vol. 66. P. 197-210.

8. Кон И. Сексология / И. Кон. Москва: Академия, 2004. 384 с.

9. Тёмкина А. Сценарии сексуальности и гендерные различия. В поисках сексуальности : сборник статей. СПб.: Дмитрий Буланин. 2002. C. 247-286.

10. Sakaluk J., Todd L.M., Milhausen R., Lachowsky N.J. Dominant Heterosexual Sexual Scripts in Emerging Adulthood: Conceptualization and Measurement. Journal of sex research. 2014. Vol. 51 (5). P. 516-531. DOI: 10.1080/00224499.2012.745473

11. Гупаловська В.А. Сексуальний сценарій у контексті адаптивності особи. Инновационная наука, образование : монография. Одесса. 2018. Глава 3. С. 72-84.

12. Каган В.Е., Исаев. Д.Н. Половое воспитание детей. Москва: Педагогика, 1988. 64 с.

13. Воронцов Д.В. КВИР-теория: перспективы психологического анализа сексуальности. Вопросы психологии. 2012. № 2. С. 153-162.

14. Кащенко Е. Психология сексуальности. Москва: Ridero, 2016. $350 \mathrm{c}$.

15.3дравомыслова Е., Тёмкина А. Сценарии сексуальности и гендерные различия. В поисках сексуальности: Сборник статей. СПб.: Дмитрий Буланин. 2002. С. 247-286. 
16. Асланян Т.С. Шевельдіна О.В. Психологічні особливості сексуальної поведінки сучасних жінок. Науковий вісник Херсонського державного університету. 2018. № 3. С. 13-17.

17. Lehmiller J. The Psychology of Human Sexuality. 2014. 400 p.

18. Suvivuo P., Tossavainen K., Kontula O. "Can There Be Such a Delightful Feeling as This?" Variations of Sexual Scripts in Finnish Girls' Narratives. Journal of Adolescent Research. 2010. 25(5). P. 669-676.

19. Simon W., Gagnon J. Sexual Scripts: Origins, Influences and Changes. Qualitative Sociology. 2003. Vol. 26, No. 4. P. 491-497.

20. Козакевич М. Сексуальное воспитание и молодёжь Европы. София. 1985. $144 \mathrm{c.}$

21. Мастерс У., Джонсон В., Колодни Р. Основы сексологии. Москва: Мир, 1998. 702 с.

22. Келли Ф.Г. Основы современной сексологии. СПб: Питер, 2000. $896 \mathrm{c}$.

\section{Information about author: \\ Hupalovska V. A.,}

Ph.D. in Psychological Sciences, Associate Professor

Lviv National I.Franko University 1, Universitetska str., Lviv, 79000, Ukraine 